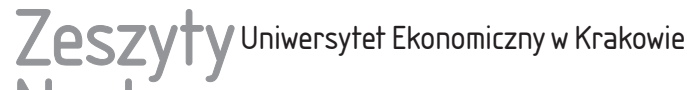 Naukowe
}

$9(957)$

ISSN 1898-6447

Zesz. Nauk. UEK, 2016; 9 (957): 71-87 DOI: 10.15678/ZNUEK.2016.0957.0905

\section{Identyfikacja znaczenia krajów w gospodarce Unii Europejskiej z wykorzystaniem miary dekompozycji zmian struktury*}

\section{Streszczenie}

Celem pracy jest analiza dynamiki zmian w gospodarce Unii Europejskiej w ujęciu strukturalnym. Analiza dotyczy jednej zmiennej makroekonomicznej - produktu krajowego brutto, liczonego zgodnie z metodologią Banku Światowego. Badaniem objęto okres 1995-2014, a elementami struktury są kraje. Wzięto pod uwagę 28 krajów tworzących obecnie Unię Europejską, stąd pojęcie Unii Europejskiej ma charakter umowny i oznacza zbiór krajów, które do 2014 r. przystąpiły do Unii.

Oryginalność metodologiczna polega na wykorzystaniu nowej miary dekompozycji zmian struktury. Struktura jest tu rozumiana jako zbiór elementów tworzących pewną całość. Porównanie wartości elementu z sumą całości pokazuje strukturę pod względem „kształtu”, natomiast wartości elementów struktury mówią o jej „rozmiarze”. Wykorzystano miarę dekompozycji do oceny udziału składników (krajów) w zmianach rozmiaru, a znak miary wskazuje, czy nastąpił wzrost, czy spadek udziału. Suma modułów wartości miary dla wszystkich składników struktury jest równa 1 dla każdej porównywanej pary jednostek czasu.

W badanym okresie PKB we wszystkich analizowanych krajach na ogół rósł. Tempo tych przyrostów było jednak różne, stąd można spodziewać się, że przestrzenna struktura PKB całej Unii ulegała zmianom.

Małgorzata Markowska, Uniwersytet Ekonomiczny we Wrocławiu, Katedra Gospodarki Regionalnej, 58-500 Jelenia Góra, ul. Nowowiejska 3, e-mail: malgorzata.markowska@ue.wroc.pl

* Artykuł powstał w ramach realizacji projektu sfinansowanego ze środków Narodowego Centrum Nauki 2015/17/B/HS4/01021. 
Słowa kluczowe: zmiany struktury, dekompozycja, gospodarka europejska, UE-28. Klasyfikacja JEL: L16, O11, O52.

\section{Wprowadzenie}

Kraje i regiony, a także miasta poddawane są ocenom i porównaniom dotyczącym wielu aspektów ich funkcjonowania. W tym celu tworzone są rankingi konkurencyjności i innowacyjności gospodarek w ujęciu globalnym lub np. na tle innych państw czy regionów Europy. Od wielu lat przedstawiane są zestawienia m.in. najlepszych krajów do życia, państw świata według wskaźnika rozwoju społecznego czy z uwzględnieniem indeksu pokoju (global peace index). Wskaźnikiem, który stanowi ważny element wielu uporządkowań, jest produkt krajowy brutto (PKB). Chociaż są zgłaszane zastrzeżenia do tego miernika, to pozostaje on jednym z najważniejszych wskaźników potencjału gospodarczego kraju czy regionu.

Gospodarka Unii Europejskiej stanowi układ złożony z 28 gospodarek krajowych. Kraje te są bardzo zróżnicowane pod względem m.in. liczby ludności, zaawansowania technologicznego, poziomu i tempa rozwoju gospodarczego, a także intensywności i skali strukturalnych transformacji [Winiecki 2016].

Celem pracy jest ocena znaczenia poszczególnych gospodarek krajowych poprzez analizę dynamiki zmian w gospodarce Unii Europejskiej w ujęciu strukturalnym, z wykorzystaniem jednej zmiennej makroekonomicznej - PKB, liczonego zgodnie z metodologią Banku Światowego w latach 1995-2014. Dla realizacji tak postawionego celu zaproponowano miarę dekompozycji zmian struktury [Markowska i Sokołowski 2016]. Rozważano 28 krajów, które obecnie tworzą Unię Europejską, stąd pojęcie UE rozpatrywanej w tym okresie ma charakter umowny (zbiór krajów, które w różnym czasie przystąpiły do Unii).

\section{Zmiany w strukturach gospodarki}

Turbulentne otoczenie, zmieniające się uwarunkowania makroekonomiczne, sprawiają, że „gospodarki nie tylko rosną, ale także zmieniają swoją strukturę w miarę rozwoju gospodarczego (mierzonego konwencjonalnie poziomem PKB per capita). W miarę jak rośnie poziom PKB per capita, zmienia się przede wszystkim struktura produkcji i zatrudnienia. Zmiany strukturalne są $\mathrm{W}$ istocie procesem ciągłym, niemniej w ramach trwałego procesu przemian strukturalnych należałoby wyróżnić dwie fazy czy dwa okresy, które przynoszą bardziej znaczące - nie tylko ilościowe - przekształcenia w gospodarce. $\mathrm{Z}$ tego też powodu warte są bardziej szczegółowej analizy" [Winiecki 2014, s. 271]. 
Strukturę rozpatrywać możemy jako konfigurację punktów w przestrzeni wielowymiarowej lub jako zbiór jednorodnych elementów tworzących pewną całość. Na jej „rozmiar” składają się wartości elementów struktury, zaś rachunkowy wynik porównania części z całością, dający w efekcie ciąg liczb nieujemnych sumujących się do jedności stanowi „kształt” struktury [Walesiak 1983, Markowska i Sokołowski 2016].

Oceniając zmiany struktury, należy spodziewać się trzech możliwości: stabilizacji, wzrostu lub spadku udziału danego elementu (danych elementów) w całości. Dla każdej z tych możliwości istnieje kilka wariantów. W tabeli 1 przedstawiono sytuację najprostszą, tj. dla dwóch składników struktury (np. struktura według płci czy też sektorów własności). Przykładowo wynik oceny zmian wskazujący na stabilizację struktury wynikać może z rzeczywistego braku zmian obu składników, ale także równoczesnego wzrostu (bądź spadku) obu składników o relatywnie taką samą wartość.

Tabela 1. Zmiany struktury - hipotetyczne możliwości (dwa składniki)

\begin{tabular}{|c|c|c|c|}
\hline \multirow{2}{*}{ Sytuacja } & \multicolumn{2}{|c|}{ Składnik } & \multirow{2}{*}{ Uwagi } \\
\hline & 1 & 2 & \\
\hline \multirow[t]{3}{*}{ Stabilizacja - brak zmian } & bez zmian & bez zmian & - \\
\hline & wzrost & wzrost & $\begin{array}{l}\text { o relatywnie tyle samo w przy- } \\
\text { padku obu składników }\end{array}$ \\
\hline & spadek & spadek & \\
\hline \multirow{4}{*}{$\begin{array}{l}\text { Wzrost udziału pierwszego } \\
\text { składnika }\end{array}$} & wzrost & bez zmian & - \\
\hline & bez zmian & spadek & - \\
\hline & spadek & spadek & większy dla drugiego składnika \\
\hline & wzrost & wzrost & $\begin{array}{l}\text { większy dla pierwszego } \\
\text { składnika }\end{array}$ \\
\hline \multirow{4}{*}{$\begin{array}{l}\text { Spadek udziału pierwszego } \\
\text { składnika }\end{array}$} & spadek & bez zmian & - \\
\hline & bez zmian & wzrost & - \\
\hline & spadek & spadek & $\begin{array}{l}\text { większy dla pierwszego } \\
\text { składnika }\end{array}$ \\
\hline & wzrost & wzrost & większy dla drugiego składnika \\
\hline
\end{tabular}

Źródło: opracowanie własne.

Wielowariantowość zmian elementów struktury, które dają ten sam wynik oceny, dały asumpt do poszukiwania miary pozwalającej na identyfikację udziału elementu w zmianach struktury [Markowska i Sokołowski 2016]. 


\section{Miara dekompozycji zmian struktury}

Proponowana przez M. Markowską i A. Sokołowskiego [2016] miara identyfikuje udział elementu w zmianach struktury, a zatem pozwala na dekompozycję zmian struktury z uwagi na rozmiar. Jeśli dla uproszczenia zapisu przyjmiemy, że porównanie dotyczy struktury w dwóch momentach oznaczonych jako 1 oraz 2 , to miarę dekompozycji zmian struktury z uwagi na rozmiar struktury określa się wzorem:

gdzie:

$$
U R_{i}=\frac{x_{2 i}-x_{1 i}}{\sum_{i=1}^{m}\left|x_{2 i}-x_{1 i}\right|},
$$

$i$ - numer składnika struktury,

$m$ - liczba składników struktury,

$x_{1 i}$ - wartość $i$-tego składnika struktury w pierwszym momencie (okresie),

$x_{2 i}$ - wartość $i$-tego składnika struktury w drugim momencie (okresie).

Suma modułów miary $U R_{i}$ jest równa 1 . Znak miary (1) wskazuje, czy wartość danego elementu struktury ( $i$-tego składnika) wzrosła (wartość dodatnia), czy spadła (wartość ujemna). Moduł wartości miary pozwala ocenić udział danego składnika w zmianach struktury, przez co umożliwia dekompozycję wartości miary zróżnicowania struktur.

\section{Znaczenie krajów w gospodarce Unii Europejskiej - wyniki oceny}

W ocenie znaczenia gospodarek wykorzystano dane o 28 krajach stanowiących obecnie Unię Europejską ${ }^{1}$. Źródło danych statystycznych stanowiły zasoby Banku Światowego [GDP... 2016].

Na rys. 1 przedstawiono szeregi czasowe ilustrujące potencjał gospodarek krajów Unii Europejskiej z uwzględnieniem wartości PKB² w latach 1995-2014.

${ }^{1} \mathrm{~W}$ artykule przyjęto następujące oznaczenia krajów: Austria - AUT, Belgia - BEL, Bułgaria - BGR, Chorwacja - HRV, Cypr - CYP, Republika Czeska - CZE, Dania - DNK, Estonia - EST, Finlandia - FIN, Francja - FRA, Niemcy - DEU, Grecja - GRC, Węgry - HUN, Irlandia - IRL, Włochy - ITA, Łotwa - LVA, Litwa - LTU, Luksemburg - LUX, Malta - MLT, Holandia - NLD, Polska - POL, Portugalia - PRT, Rumunia - ROU, Słowacja - SVK, Słowenia - SVN, Hiszpania ESP, Szwecja - SWE, Wielka Brytania - GBR.

${ }^{2}$ Produkt krajowy brutto wyrażony w dolarach amerykańskich, w cenach bieżących. Zgodnie z definicją Banku Światowego PKB wyrażone w cenach kupującego i rozumiane jako suma wartości dodanej brutto wszystkich producentów w danym kraju plus podatki na produktach minus subsydia nieuwzględniane w cenach towarów. W obliczeniach nie uwzględniano deprecjacji środków 
W całym analizowanym okresie widoczna jest wyraźna dominacja sześciu kluczowych gospodarek, w ramach których sytuacja była na ogół stabilna pod względem kolejności, poza Wielką Brytanią i Francją, dla których występuje kilkukrotna zamiana na pozycjach 2 i 3. W 2014 r. wartość PKB dla Wielkiej Brytanii w efekcie sześcioletniego trendu wzrostowego ponownie przewyższyła wartość PKB we Francji (przy stagnacji wartości tego miernika we Francji).

Na rys. 2 przedstawiono PKB dla krajów o zbliżonym jego poziomie, a zatem z pominięciem krajów, których PKB jest istotnie wyższe (Niemcy, Wielka Brytania, Francja, Włochy, Hiszpania i Holandia.

Do najmniejszych gospodarek Unii Europejskiej - ocenianych z perspektywy poziomu PKB - zaliczają się mln USD w 2014 r.), Estonia (4373,7 mln USD w 1995 r. i 26 485,2 mln USD w 2014 r.), Łotwa (5785,1 mln USD w 1995 r. i 31 286,8 mln USD w 2014 r.), Litwa (7870,8 mln USD w 1995 r. i 48 353,9 mln USD w 2014 r.), Cypr (9914,9 mln USD w 1995 r. i 23 226,2 mln USD w 2014 r.), Bułgaria (13 063,4 mln USD w 1995 r. i 56 717,1 mln USD w 2014 r.), zaś następne były Słowenia, Luksemburg, Chorwacja i Słowacja. Również w obrębie ostatnich miejsc pod względem poziomu PKB miały miejsce zmiany. W 2014 r. najniższy poziom PKB odnotowały następujące państwa: Malta, Cypr, Estonia, Łotwa, Litwa, Słowenia, Bułgaria, Chorwacja, Luksemburg, Słowacja i Węgry.

Udziały poszczególnych gospodarek krajowych w PKB Unii Europejskiej przedstawiono na rys. 3. Jak widać, chociaż wartości PKB kluczowych gospodarek UE miały tendencję rosnącą, to udziały tych gospodarek w PKB Wspólnoty mają raczej tendencję malejącą. Dość wskazać, iż udział PKB Niemiec w PKB Unii Europejskiej wynosił w 1995 r. 27,2\%, zaś w 2014 r. 20,9\% (oznacza to spadek z ponad 1/4 do 1/5 ogólnego PKB krajów UE).

Oceniając wartości miary udziału w zmianach struktury (wzór (1)), gdzie elementy struktury to 28 krajów, można wskazać na „,złoty okres” stabilizacji krajowych gospodarek w latach 2002-2008, gdy wszystkie wartości miary (poza Wielką Brytanią w 2008 r.) były dodatnie, co oznaczało wzrost PKB we wszystkich krajach. Dwa kolejne lata (2009-2010) to dla większości gospodarek okres kryzysu - odnotowano ujemne wartości miary. Wyjątkami są Wielka Brytania (miara $U R$ na poziomie 0,19$)$, Szwecja $(0,13)$, Polska $(0,10)$ oraz takie kraje, jak Czechy, Dania, Węgry, Luksemburg, Malta, Rumunia i Słowacja, w których miara

trwałych oraz kosztów degradacji i wyczerpywania się bogactw naturalnych. Dane są wyrażone w dolarach amerykańskich, w cenach bieżących. Wielkości w dolarach uzyskano, przeliczając dane w walucie lokalnej na dolary według jednego kursu. Dla kilku krajów, dla których kursy oficjalne są inne niż te stosowane w wymianie walut, zastosowano alternatywny sposób przeliczenia.

${ }_{3}^{3}$ Podano ostatnie dziesięć krajów w kolejności od najniższego PKB dla danych z 1995 r. 


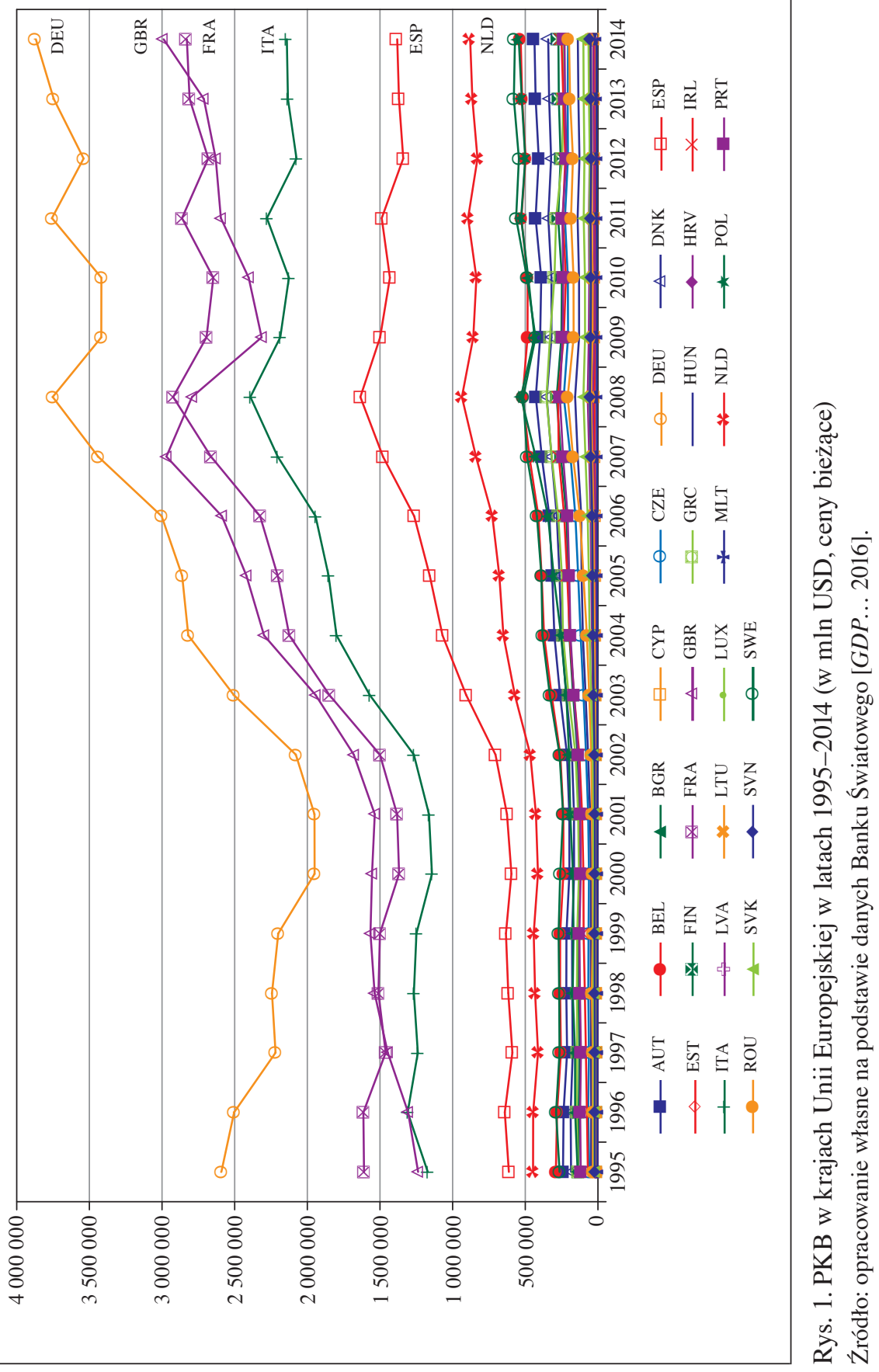




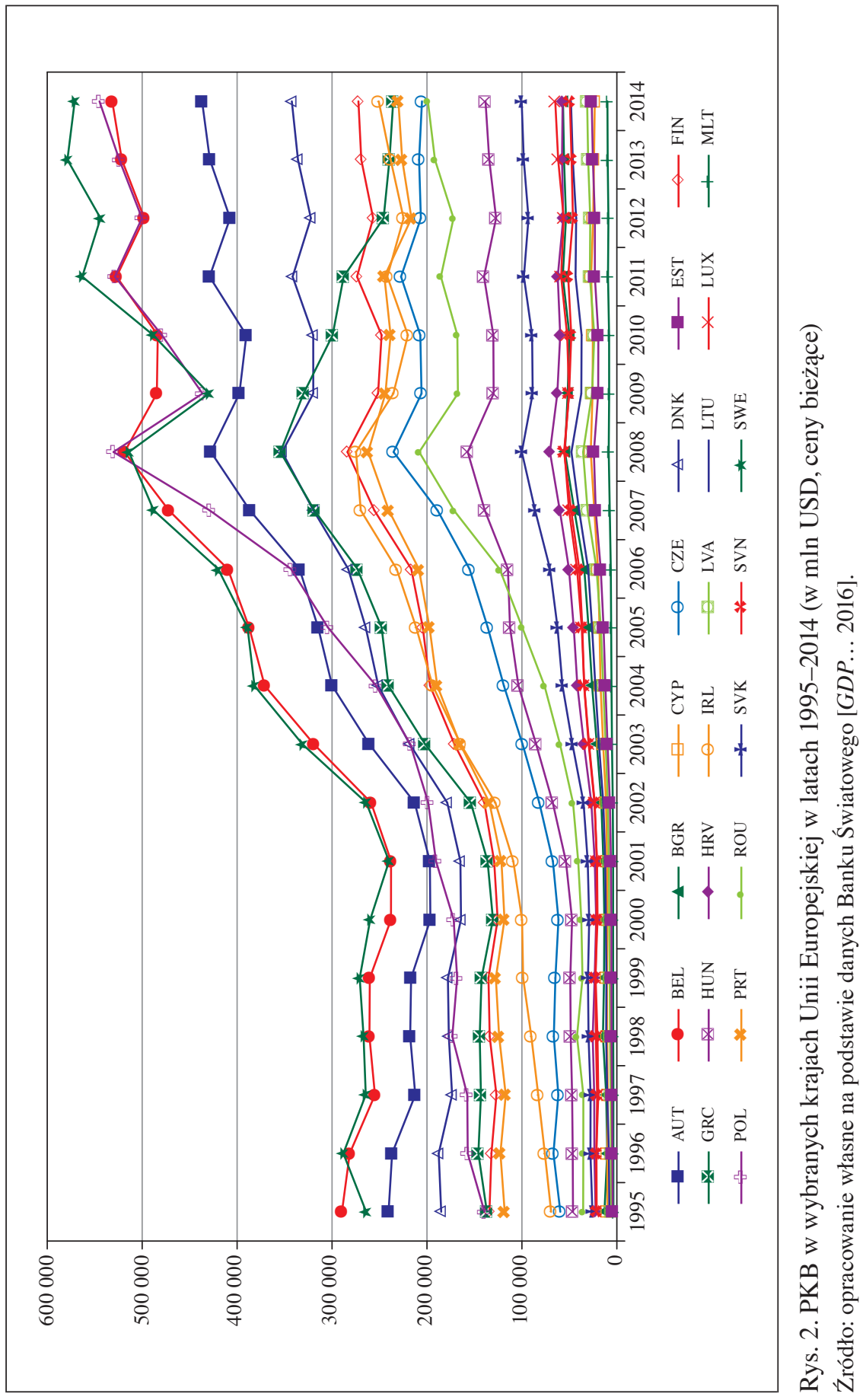




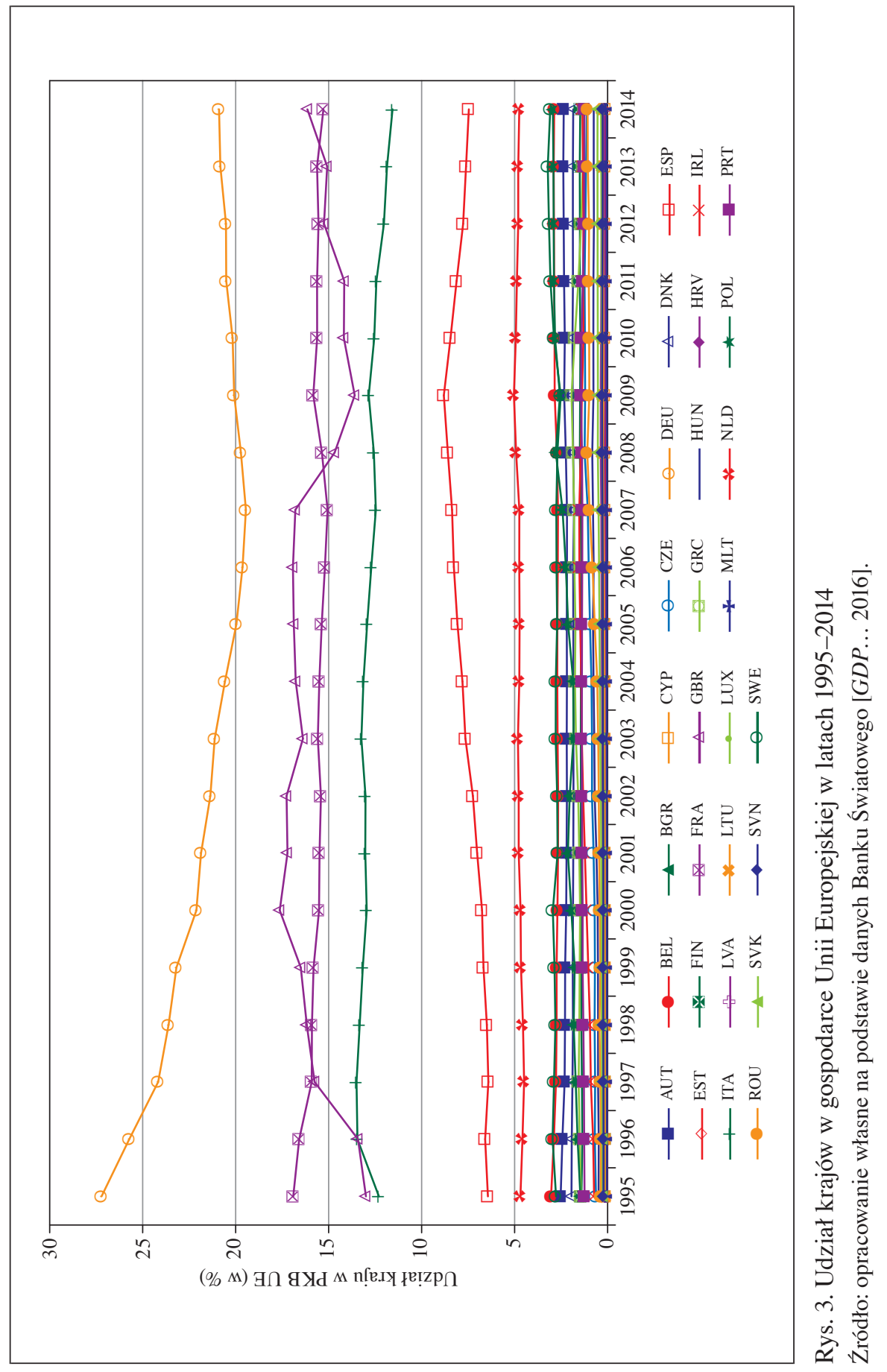


UR była także dodatnia i oscylowała w granicach od 0,0001 (MLT) do 0,0042 (LUX) w $2010 \mathrm{r}$.

W kolejnym roku nastąpiła poprawa ocenianej z wykorzystaniem PKB sytuacji gospodarczej krajów UE (jedynie w Grecji miara $U R$ była ujemna i wynosiła $-0,0083$, podobnie w następnych latach: $-0,037,-0,008 \mathrm{i}-0,007)$. W $2012 \mathrm{r}$. obserwowany jest natomiast kolejny spadek tego wskaźnika (ponownie poza Wielką Brytanią), a w 2013 r. poprawa dla większości krajów (z wyłączeniem wspomnianej wcześniej Grecji i Cypru). W 2014 r. jedynie dla pięciu krajów (Grecja, Chorwacja, Cypr, Czechy i Szwecja) miara UR była ujemna (por. rys. 4).

W następnym etapie analizy zbadano trendy liniowe miar udziału w zmianach struktury PKB UE dla wszystkich krajów. Na poziomie istotności 0,05 tylko jeden trend okazał się istotny - dla Niemiec. W związku z tym w dalszej ocenie zdecydowano się wykorzystać średnie (por. rys. 5). Na osi poziomej zaznaczono średni udział w strukturze, natomiast na osi pionowej średni udział w zmianach struktury (liczony jako średnia modułów miary UR). Współczynnik korelacji wynosi 0,986, co oznacza, że to kraje o dużym PKB mają duży udział w zmianach struktury.

Rozpatrując pozycje krajów z uwagi na udział w zmianach struktury PKB UE w porównaniu z ich pozycjami z uwagi na udział w strukturze (rys. 6), należy wskazać, iż pierwsza szóstka krajów jest taka sama (także pod względem kolejności). Gospodarka Polski, która jest dopiero 10. z uwagi na udział w strukturze PKB Unii Europejskiej, plasuje się jednak na 7. miejscu z uwagi na wpływ na zmiany struktury PKB UE. W państwach europejskich o średnim poziomie PKB występuje najsłabszy związek pomiędzy średnim udziałem w strukturze a średnim udziałem w jej zmianach.

Przewagę udziału w zmianach struktury PKB UE nad udziałem w strukturze przedstawiono na rys. 7. Prostokątem obwiedziono kraje, w których różnica między tymi udziałami nie przekraczała jednego punktu procentowego. Największe przewagi dotyczyły gospodarek Polski, Hiszpanii i Wielkiej Brytanii.

Kształtowanie się miary w wybranych krajach - tych, dla których na rys. 7 udział w zmianach struktury był zbyt duży lub zbyt mały w stosunku do udziału w strukturze - przedstawiono na rys. 8-12.

W przypadku polskiej gospodarki sytuacja kształtowała się bardzo optymistycznie (rys. 8), gdyż niemal przez cały czas następowało przesuwanie się w prawo wykresu, co oznacza zwiększający się udział polskiej gospodarki w gospodarce zjednoczonej Europy. Warto także skonstatować, że PKB liczony według metodologii Banku Światowego zanotował spadek jedynie w 1999, 2009 i $2012 \mathrm{r}$. 


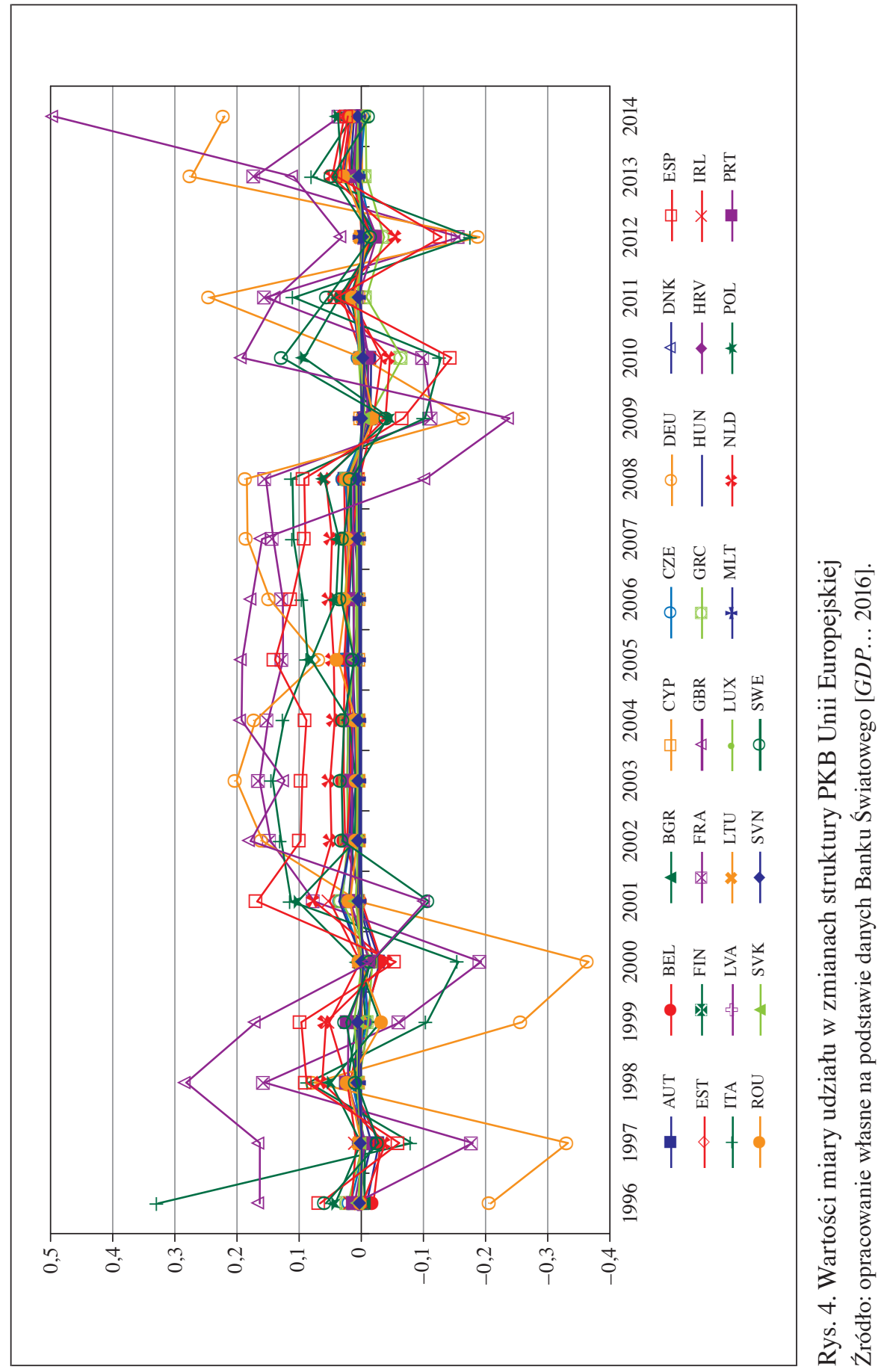




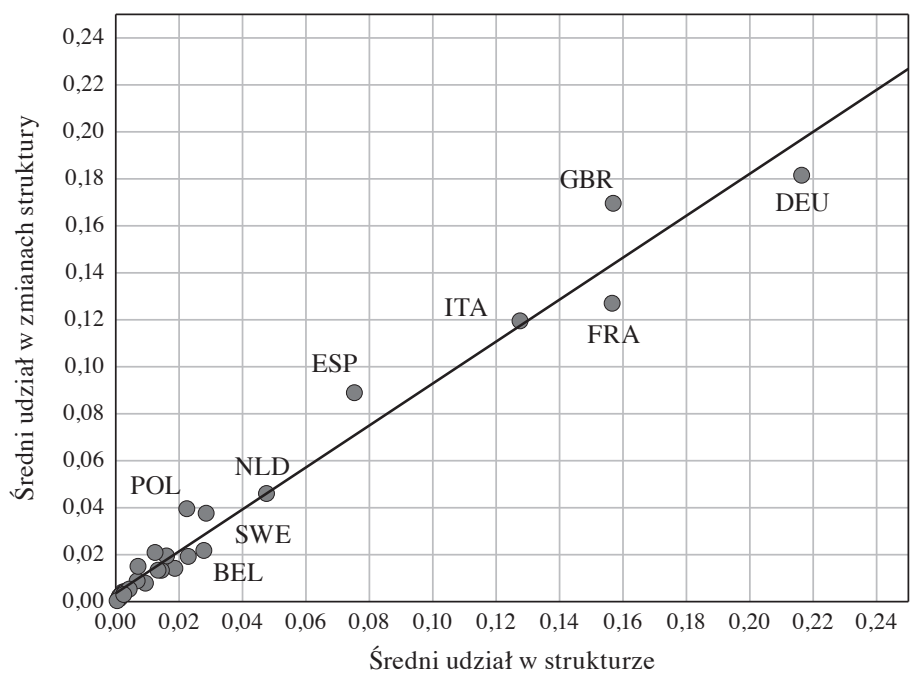

Rys. 5. Średnie udziały w strukturze PKB UE i zmianach tej struktury kraje Unii Europejskiej

Źródło: opracowanie własne na podstawie danych Banku Światowego [GDP... 2016].

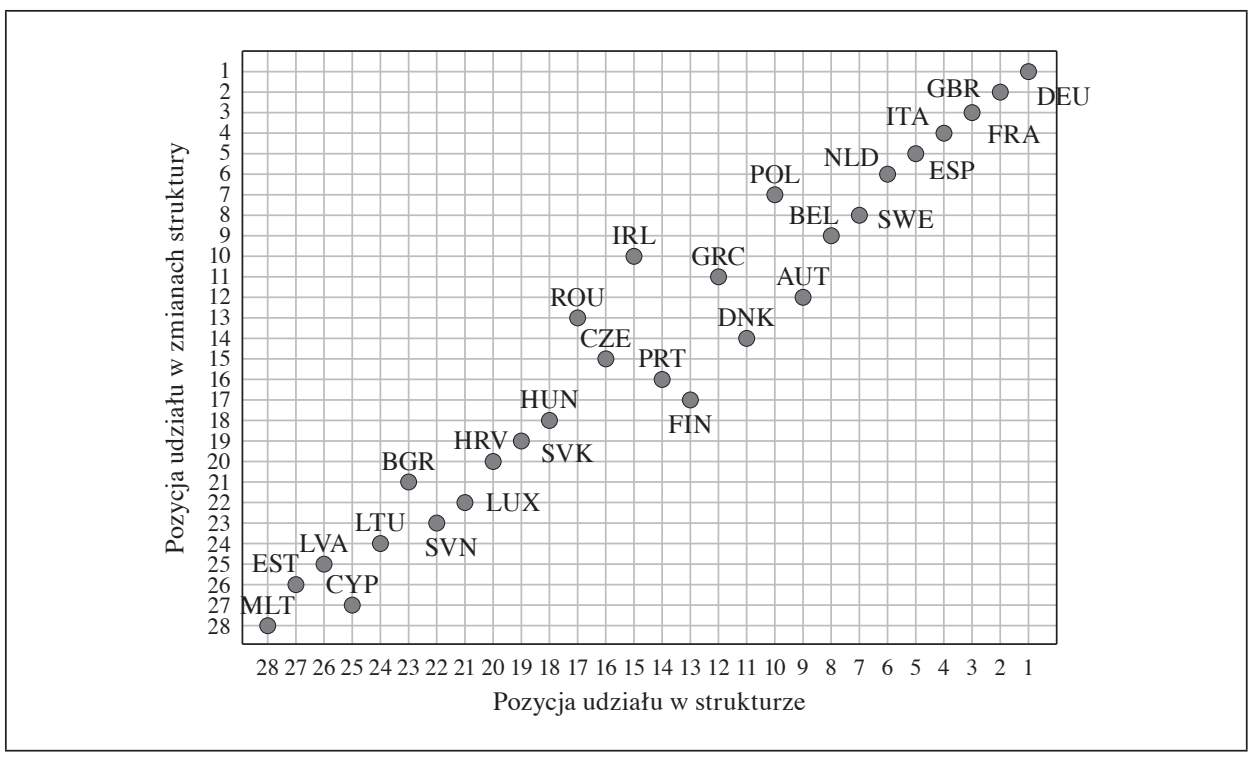

Rys. 6. Zestawienie pozycji krajów Unii Europejskiej: udział w strukturze PKB UE i udział w zmianach tej struktury

Źródło: opracowanie własne na podstawie danych Banku Światowego [GDP... 2016]. 


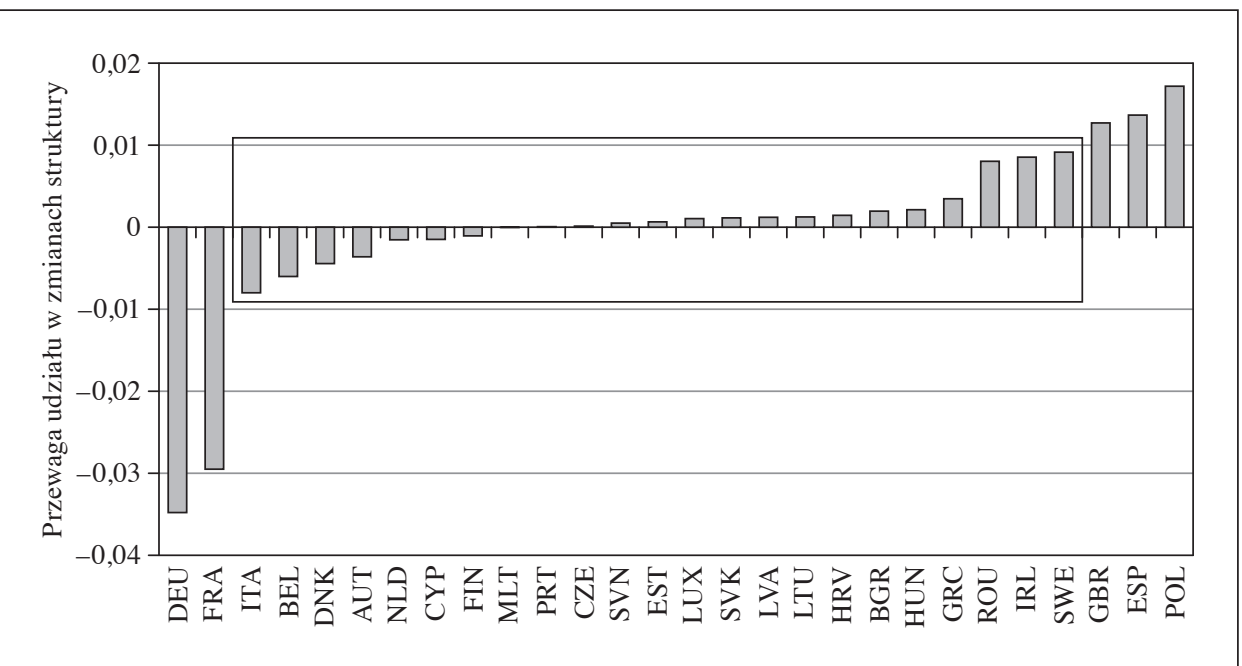

Rys. 7. Przewagi udziału w zmianach struktury PKB UE - kraje Unii Europejskiej Źródło: opracowanie własne na podstawie danych Banku Światowego [GDP... 2016].

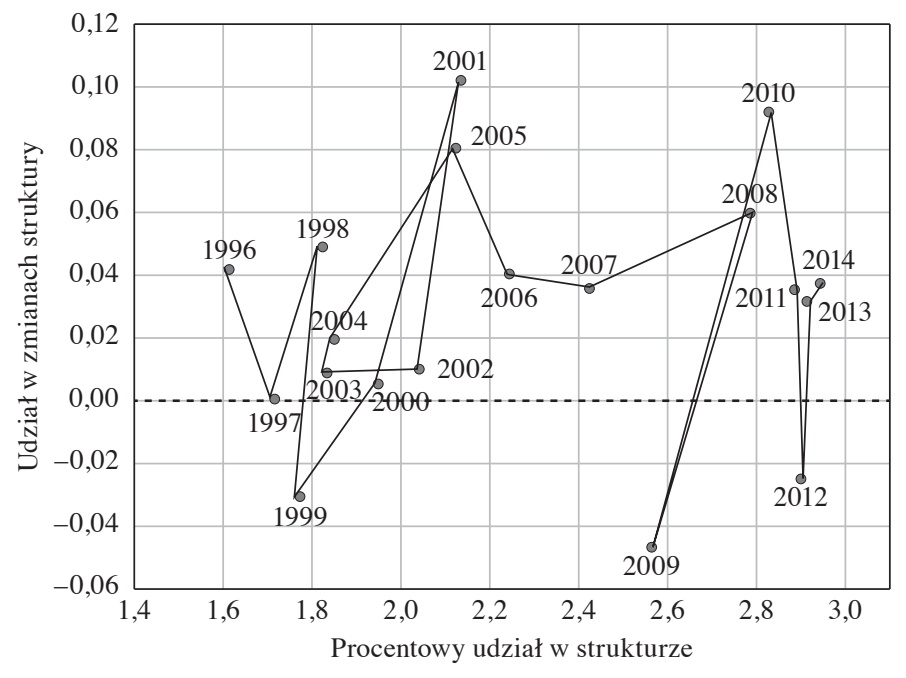

Rys. 8. Udział w zmianach struktury PKB UE i procentowy udział w tej strukturze Polska

Źródło: opracowanie własne na podstawie danych Banku Światowego [GDP... 2016]. 


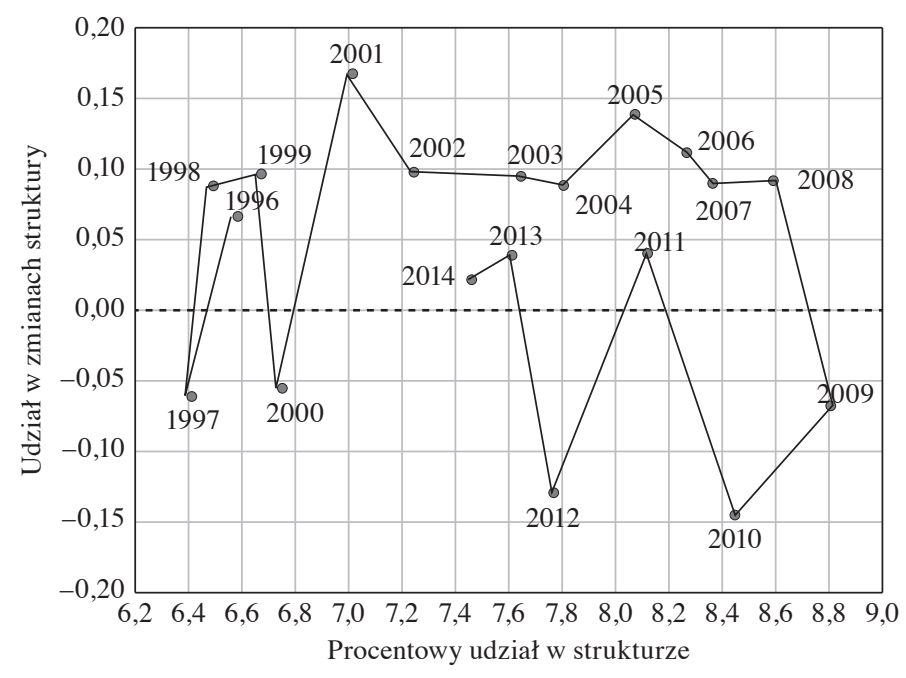

Rys. 9. Udział w zmianach struktury PKB UE i procentowy udział w tej strukturze Hiszpania

Źródło: opracowanie własne na podstawie danych Banku Światowego [GDP... 2016].

W Hiszpanii (rys. 9) bardzo dobry okres w porównaniu z całą UE to lata 20012008, natomiast kolejne lata przyniosły spadek znaczenia Hiszpanii w gospodarce UE.

W latach 1995-2014 miały miejsce duże zmiany dotyczące znaczenia gospodarki Wielkiej Brytanii. Interesujące wydaje się powiązanie zmian ze sprawującymi władzę w tym kraju premierami. Wzrost znaczenia Wielkiej Brytanii zaczął się za rządów Johna Majora (Partia Konserwatywna), ale od maja 1997 r. premierem był Tony Blair (Partia Pracy) - w okresie tym utrzymywała się tendencja wzrostowa z wyjątkiem 2001 r. Lata rządów Gordona Browna (Partia Pracy) - 2007-2009 - oznaczały hamowanie gospodarki. Dopiero pod przywództwem Davida Camerona (Partia Konserwatywna) w 2010 r. miał miejsce zwrot (nastąpiły pozytywne zmiany i wzrost znaczenia Wielkiej Brytanii w UE), a w 2014 r. odnotowano duży sukces w tym zakresie (por. rys. 10).

We Francji w analizowanych latach wstąpiły duże turbulencje (rys. 11): 1) nastąpił spadek znaczenia Francji w gospodarce UE w badanym okresie o ok. 1,3 punktu procentowego, 2) aż w sześciu latach odnotowano spadek PKB.

Widoczny jest także spektakularny spadek udziału Niemiec w gospodarce UE (rys. 12) z prawie 26\% w 1995 r. do 19,5\% w 2006 r. oraz spadek PKB w 2009 r. i 2012 r., przy czym w następnych latach nastąpił wzrost tego wskaźnika. 


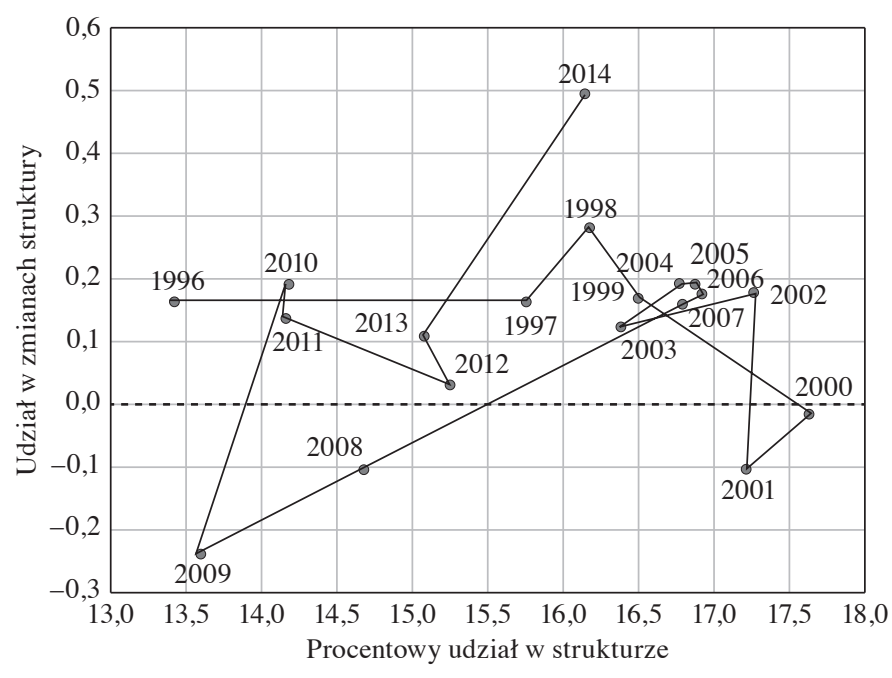

Rys. 10. Udział w zmianach struktury PKB UE i procentowy udział w tej strukturze Wielka Brytania

Źródło: opracowanie własne na podstawie danych Banku Światowego [GDP... 2016].

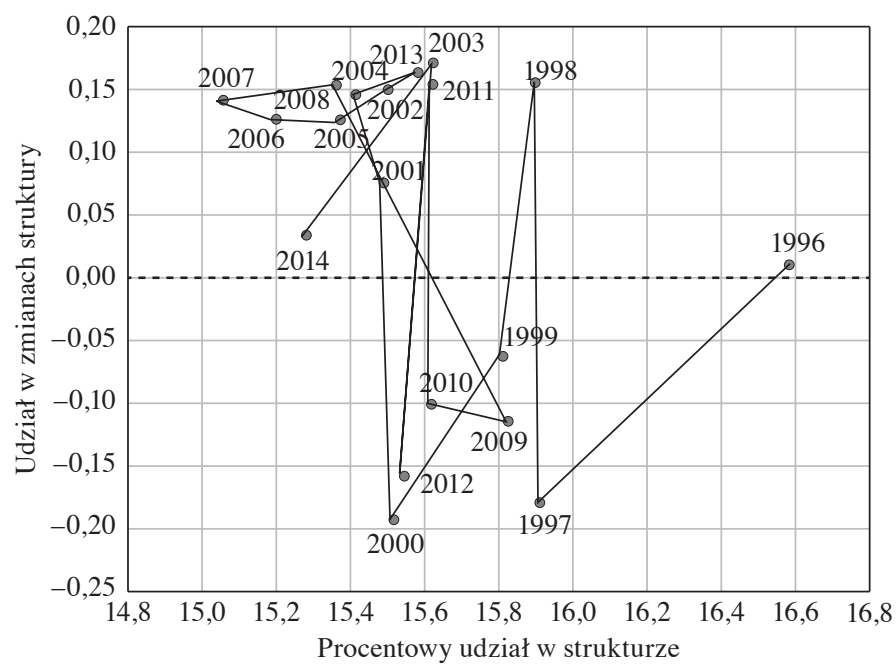

Rys. 11. Udział w zmianach struktury PKB UE i procentowy udział w tej strukturze Francja

Źródło: opracowanie własne na podstawie danych Banku Światowego [GDP... 2016]. 


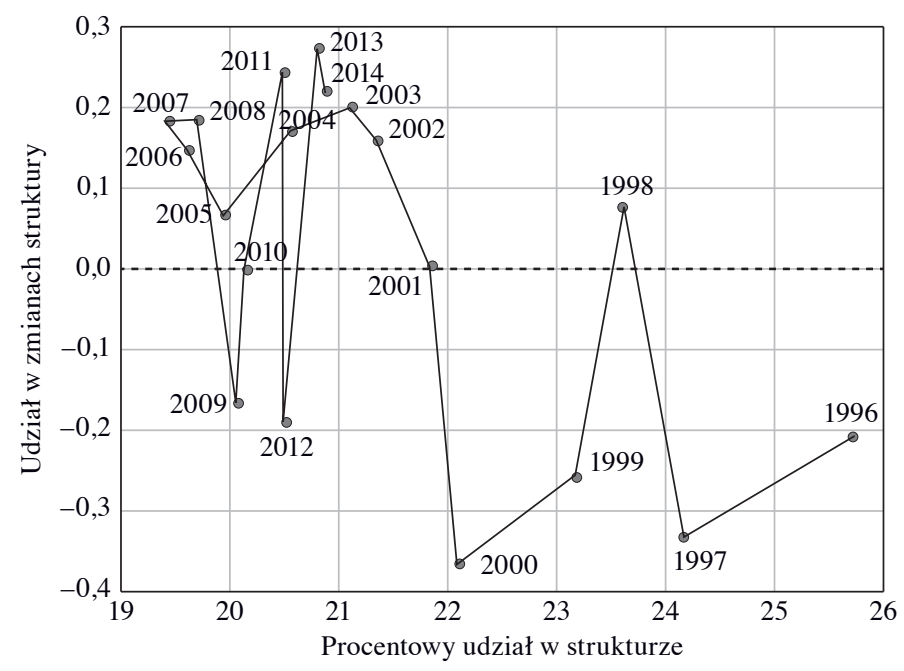

Rys. 12. Udział w zmianach struktury PKB UE i procentowy udział w tej strukturze Niemcy

Źródło: opracowanie własne na podstawie danych Banku Światowego [GDP... 2016].

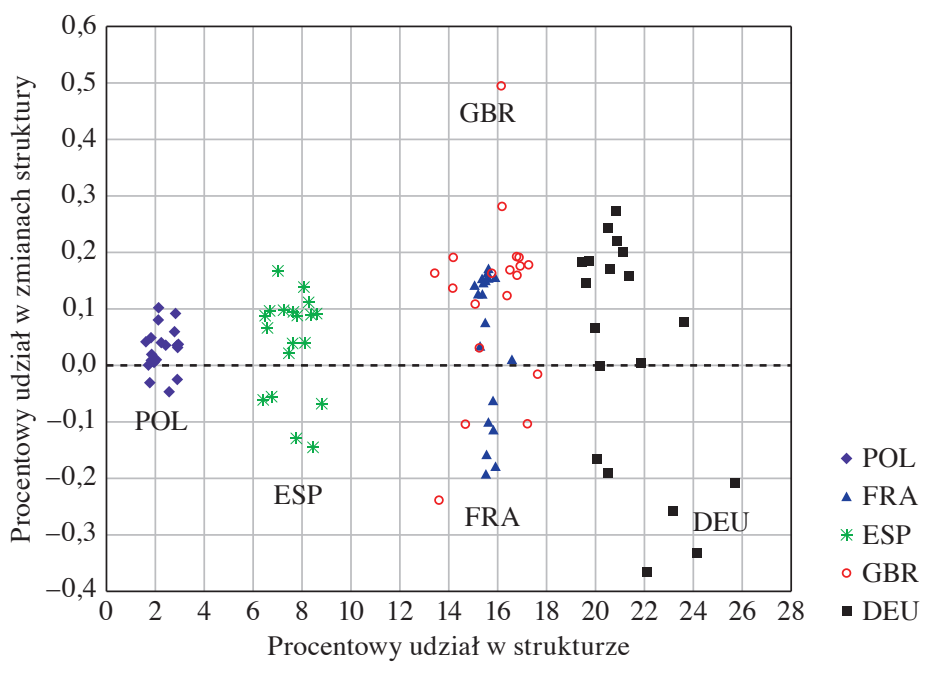

Rys. 13. Udział w zmianach struktury PKB UE i procentowy udział w tej strukturze wybrane kraje Unii Europejskiej

Źródło: opracowanie własne na podstawie danych Banku Światowego [GDP... 2016]. 
Zestawienie wyników dotyczących procentowego udziału w zmianach struktury i procentowego udziału w strukturze PKB UE opisanych wyżej pięciu krajów razem przedstawiono na rys. 13.

Niemcy mimo różnych zawirowań są od lat największą gospodarką UE. W latach kryzysu nastąpiły 20-40-procentowe zmiany w strukturze PKB UE. Ujemny procentowy udział w zmianach struktury dotyczył lat 1996-2000, w kolejnych latach następowała głównie poprawa, stąd można mówić o istotnym trendzie dotyczącym wartości miary $U R$.

Analizując udział w PKB Unii Europejskiej gospodarek Francji i Wielkiej Brytanii, można mówić o ich ,przeplataniu się”. W przypadku danych dla Francji sześciokrotnie procentowy udział w zmianach struktury był ujemny, podczas gdy dla Wielkiej Brytanii sytuacja tak miała miejsce czterokrotnie. Ponadto dla Wielkiej Brytanii odnotowano największą wariancję w udziale w zmianach struktury.

W przypadku gospodarki Polski udział w strukturze PKB Wspólnoty jest, co prawda, mały (ale rosnący z 1,5\% do 3\% w analizowanym okresie), a ujemny procentowy udział w zmianach struktury odnotowano jedynie trzy razy (w 1999, 2009 i 2012 r.).

\section{Zakończenie}

Na podstawie przedstawionych wyników oceny zmian znaczenia krajów w gospodarce Unii Europejskiej można wskazać, że:

- miara $U R$ pozwala na ukazanie udziału składników struktury w zmianach rozmiaru struktury PKB UE,

- miara ta umożliwia pomiar tego udziału z uwzględnieniem zmian wielkości wszystkich pozostałych składników struktury,

- można interpretować wartość $U R$ pod względem udziału w zmianach oraz kierunku zmiany wartości (spadek/wzrost) lub tylko poprzez moduł miary (tylko „siła” udziału w zmianach),

- przeprowadzona analiza struktury PKB Unii Europejskiej w latach 19952014 wykazała, że sześć największych pod względem gospodarczym krajów ma największe udziały w zmianach struktury,

- kraje Unii znajdujące się na kolejnych dziesięciu pozycjach (średnie) wykazują stosunkowo największe odstępstwo od tej prawidłowości,

- mimo to korelacja między wielkością gospodarki a jej udziałem w zmianach struktury jest bardzo wysoka,

- w porównaniu z innymi gospodarkami europejskimi polska gospodarka ma o wiele większy udział w zmianach struktury, niż to wynika z jej potencjału. 


\section{Literatura}

GDP (Current US\$) [2016], World Bank, http://data.worldbank.org/indicator/NY.GDP. MKTP.CD (dostęp: 15.04.2016).

Markowska M., Sokołowski A. [2016], Metoda dekompozycji zmian struktury, „Prace Komisji Geografii Przemysłu Polskiego Towarzystwa Geograficznego”, vol. 30, nr 3.

Walesiak M. [1983], Podobieństwo wielkości (skali) oraz kształtu (formy) w złożonych badaniach strukturalnych, ,Wiadomości Statystyczne”, nr 3.

Winiecki J. [2014], Przekształcenia strukturalne w procesie rozwoju gospodarczego. Modyfikacje i rozszerzenia, „Ruch Prawniczy, Ekonomiczny i Socjologiczny”, vol. 76, nr 2, https://doi.org/10.14746/rpeis.2014.76.2.20.

Winiecki J. [2016], Shortcut or Piecemeal: Economic Development Strategies and Structural Change, Central European University Press, Budapest, https://muse.jhu.edu/ (dostęp: 15.06.2016).

\section{Identifying the Importance of Countries in the EU Economy Using a Measure for Structural Changes Decomposition}

(Abstract)

The main aim of the paper is to analyse the structural dynamics in the EU economy. It is based on one macroeconomic variable - GDP, calculated using the methodology employed by the World Bank. The research covers the years 1995-2014. The 28 member states that belonged to the EU at the end of the period are treated as the structural elements of the European economy.

A new measure for decomposing structural changes is used in the analysis. It takes into account changes in the values of the structural components, which is called the "size" of the structure (as opposed to „shape”, which concerns only the share of components). The decomposition measure makes it possible to evaluate changes in the importance of individual countries in the European economy, and the sign of a measure shows whether an increase or decrease has been observed. The sum of absolute values of decomposition measure comes out to one for each pair of time units compared.

GDP grew - more or less - in all of the countries during the period analysed, but the rates of growth differed (by country and time period), which produced changes in its structure.

Keywords: structural changes, decomposition, European economy, EU 28. 